\title{
Deconvoluting effects of vine and soil properties on grape berry
}

\section{composition}

\author{
A. Zerihun ${ }^{1,4}$, L. McClymont ${ }^{2}$, D. Lanyon ${ }^{3}$, I. Goodwin², M. Gibberd ${ }^{1}$
}

${ }^{1}$ Curtin University, Department of Environment and Agriculture, Margaret River Education Campus, PMB1, Margaret River, WA 6285, Australia; ${ }^{2}$ Department of Primary Industries, PMB1, Tatura, Vic 3616, Australia; ${ }^{3}$ MWH Australia, 147 Pirie Street, Adelaide, SA 5000, Australia.

${ }^{4}$ Corresponding author: a.zerihun@curtin.edu.au; fax: +61 897579395

\begin{abstract}
BACKGROUND: Grape berry composition is influenced by several factors including grapevine and soil properties and their interactions. Understanding how these factors interact to determine berry composition is integral to producing berries with desired composition. Here we used extensive spatio-temporal data to identify significant vine and soil features that influence Shiraz berry composition.
\end{abstract}

This article has been accepted for publication and undergone full peer review but has not been through the copyediting, typesetting, pagination and proofreading process, which may lead to differences between this version and the Version of Record. Please cite this article as doi: 10.1002/jsfa.6705 
RESULTS: The concentrations of berry flavonoids (anthocyanins, tannin and total phenolics), total soluble solids and $\mathrm{pH}$ were typically negatively associated with canopy, crop and berry size factors whereas titratable acidity was positively associated. The strengths of the associations, however, were generally greater with the crop and berry size factors than with the canopy size factor. The analyses also resolved separate influences of berry and crop size on berry composition. Soil properties had significant influences on berry composition; however, when influences of soil factors on vineattributes were accounted for, the apparent effects of soil factors on berry composition were largely non-existent.

CONCLUSION: At each site, variations in berry composition were more strongly associated with crop and berry size than with canopy size factors. Apparent influences of soil properties on berry composition are indirect, being mediated via their effects on vine attributes (canopy, crop and berry sizes).

Keywords: anthocyanin; berry composition; berry size; canopy size; crop size; flavonoids;

NDVI; phenolics; plant cell density; tannin; soil chemical and physical properties; Vitis vinifera L. Shiraz

\section{INTRODUCTION}

Grape berry 'quality' is one of the cardinal variables that determines wine quality ${ }^{1}$. Berry 'quality', however, is a generic term that refers to levels of a diverse range of berry chemical constituents. While the specific chemical components or combinations thereof that determine 
the overall 'quality' of the resultant wine are difficult to pinpoint ${ }^{1,2}$, it is generally understood that berry flavonoids (anthocyanins, tannins and total phenolics), titratable acidity (TA), pH and total soluble solids (TSS) are some of the key berry attributes that affect wine quality ${ }^{1,3}$. Clearly, the concentrations of these berry components are determined in the vineyard through the combined influences of several factors. These include: vine-related properties (crop $\operatorname{size}^{4,5}$, berry size ${ }^{6}$ and canopy size $e^{7-10}$ ), the root zone soil physico-chemical properties ${ }^{9,11-14}$, and the meso- and micro-climate that prevail during and possibly even prior to berry development ${ }^{15-19}$. Understanding how these factors (interact to) influence the levels of the various berry chemical constituents at harvest is integral to producing berries with desired compositional characteristics.

Traditionally, the approach taken towards understanding how the environment, management and vine-related properties influence berry composition has involved conducting experiments in which only few factors are manipulated and individual or interactive effects are evaluated ${ }^{4,6-8,10,12,15,16,18,20,21}$. Such approaches have provided us considerable insights, and advanced our understanding, on how a single or few interacting factors influence berry composition. Notwithstanding the clear benefits of manipulative experiments, there is typically a logistical limit as to how many factors can be simultaneously examined (in spite of the fact that, in a vineyard, vines and grapes are invariably exposed to a much wider range of factors). Furthermore, as suggested in Smart et $a l^{7}$, in manipulative experiments, the imposed treatments induce changes to the vine itself and thus it is often unclear whether the observed responses in berry composition are direct effects or indirect mediated via changes in vine attributes.

More recently, there has been an emerging paradigm towards examining hyper-factor effects on berry composition in situ ${ }^{9}$. In this approach, measurements are taken to obtain a fuller characterisation of sample vines and their immediate milieu along with measures of 
berry composition. This framework was employed in this study. Specifically, the method used here involved selecting vines that captured the full range of variation in each study vineyard with respect to: (1) vine-related characteristics (sizes of crop, berry and canopy), (2) the root zone soil physical and chemical properties, and (3) some components of berry composition (anthocyanins, tannins, total phenolics, TSS, TA and $\mathrm{pH}$ ). The aim was to tease out the soil- and vine-factors for each site that have the strongest association with, and by inference influence on, berry composition using a combination of multi- and bi-variate analyses.

\section{EXPERIMENTAL}

\section{Site and management descriptions}

The data reported here were collected as part of a larger project that investigated influences of soil, climate and management on Shiraz yield, fruit and wine composition at five commercial vineyards across southern Australia over a period of three years (2005/06 to 2007/08). The study vineyards were located in the Great Southern (GS, Western Australia), Langhorne Creek (LC, South Australia), the Goulburn Valley (GV) and the Murray Darling (MD) both sites in Victoria, and Riverina (RV, New South Wales). Some characteristics of the study vineyards are given in Table 1 . Average $(n=100$ cores) textural properties of the soils in the top $80 \mathrm{~cm}$ of the profile ranged from sandy loam at the MD site to clay at the GS (Table 1). Soils across the sites had varying levels of total carbon and total N, and other fertility and salinity indicators (Table 1). Soil $\mathrm{pH}$ at all sites ranged from neutral to slightly alkaline. The average growing season temperature (October - April inclusive) across regions had a $4.5^{\circ} \mathrm{C}$ spread (from $16.8^{\circ} \mathrm{C}$ at GS to $21.5^{\circ} \mathrm{C}$ at MD) (Table 1 ). All five sites were characterised by low average annual rainfall ranging from $209 \mathrm{~mm}$ (MD) to $515 \mathrm{~mm}$ (GS). The average annual reference crop evapotranspiration, $\mathrm{ET}_{0}$, was high reaching more than 2 to 
7 times the annual rainfall depending on site (Table 1). All sites used drip irrigation during the growing season to moderate the impact of the large deficit between rainfall supply and atmospheric demand. The amount of irrigation applied, however, differed considerably across sites: ranging from $35 \mathrm{~mm}$ at the GS to $471 \mathrm{~mm}$ at the RV site (Table 1).

\section{Selection of sampling vines}

At each site, 100 sample vines were selected and tagged at the beginning of the study. These vines were used in all subsequent years (2005/06-2007/08) for all the measurements reported here. Details of the sample vines selection procedure are given elsewhere ${ }^{22,23}$. Briefly, the sample vines were selected using a procedure that ensured the selected vines represented the full range of variation in vine size and soil characteristics of each vineyard. This was facilitated by acquiring high-density gridded data on soil (electromagnetic induction (EM38) or $\gamma$-radiometric surveys taken in 2005) and vine properties (depending on site from historical spatial yield monitoring data, satellite or airborne imagery or trunk diameter measures taken in 2005). These soil- and vine-property data were jointly analysed by a non-hierarchical ( $k$ means) clustering procedure to subdivide each vineyard into five zones such that the differences between zonal means are maximised while the variation within each zone is minimised. Once the zones were "delineated”, the number of vines selected from each zone was determined in proportion to the standard deviation of each zone and the size/area of the zones.

\section{Vine canopy size/density estimation}

Indices of vine canopy size in the form of plant cell density (PCD, R780/R675), normalised difference vegetation index (NDVI, (R780-R675)/(R780+R675)) and “vigour” (R550/R675), where $\mathrm{R}$ is reflectance at the indicated wavelength, were determined from aerial imagery of the study blocks as described in Zerihun et $a^{24}$. Acquisitions of the aerial imagery data were 
done during veraison in each of the three years of study by SpecTerra Services using a HiRAMS digital multi-spectral camera (SpecTerra Services Pty Ltd., Perth, Western Australia). Vine and non-vine material were determined by SpecTerra Services using an "inhouse” algorithm. For each target vine, the three canopy size measures described above were estimated with and without the mid-row cover.

\section{Soil sampling and analysis}

Duplicate soil samples at each of the 100 target vine location were taken $0.2 \mathrm{~m}$ from the drip irrigation emitter at 0-0.1, 0.15-0.25, 0.35-0.45 and 0.7-0.8 m depth increments. The duplicate samples were combined for analysis. Soil electrical conductivity, $\mathrm{pH}_{\mathrm{Ca}}$, chloride, sand/clay/silt, bulk density and the volumetric water contents were estimated for each depth increment. Full details of the analytical methods are given in Goodwin et $a^{23}$. Readily available water content $(\mathrm{mm} / \mathrm{m})$ was estimated, as the difference between predicted volumetric water content values at 0.01 and $0.05 \mathrm{MPa}$ soil matric suction, using Mid Infrared Spectroscopy $^{25}$. Additional soil chemistry (total N, total C, exchangeable cations and macro and micro-nutrients) characterisation of the vineyard sites were carried out on samples from the 0-0.1 and 0.15-0.25 m depth increments for 40 of the 100 target vine locations at each site ${ }^{23}$.

\section{Yield determination, and bunch and berry sampling}

Yield was determined for each of the 100 sample vines immediately prior to commercial harvest. The method of sampling for yield determination differed across sites. In the hot climate and high-volume irrigated sites where vines had large canopies (MD and RV), yield was determined by harvesting a $0.5 \mathrm{~m}$ transect of the target vines. The sampling transect was located to one side of the vine trunk centred at the mid-point of the cordon. In the warm

climate locations (GV and LC), the entire sample vine was harvested for yield determination. At the GS site, target vine yield was determined by harvesting all bunches within a $1.8 \mathrm{~m}$ 
transect centred on the target vine trunk (i.e. vine spacing distance). For all sites, yield of individual sample vines was standardised to a unit area to account for the differences in sampling methods for yield determination. This standardised yield is hereafter referred to as crop size sensu Keller $^{26}$. In all cases, bunches were counted and recorded as they were harvested. The bunches from each sample vine were weighed in the field using a $30 \pm 0.01 \mathrm{~kg}$ balance, and net weights recorded. Following bunch weighing, 30 representative bunch subsamples were retained from each sample vine for determination of berry weight and composition (see below). The bunch samples were transported to the respective laboratories and stored at $4^{\circ} \mathrm{C}$ until processed (within $48 \mathrm{~h}$ from harvest). In the laboratory, approximately $25 \%$ of the berries were removed intact from each of the 30 bunch samples. The position on the bunch from which the berries were removed was alternated between the top and bottom halves of the bunch, and removing all intact berries from the right or left portion of the top or bottom half. This sampling ensured that the sampled berries were representative of berries from all parts of the bunch (top, bottom, inner, outer, sun-exposed and shaded). The berry samples were gently mixed by hand. Subsequently, a random subsample of 150 berries was taken to determine average berry weight for each sample vine. Of the remaining berries, two additional sets of samples were taken: one set was used for determination of TSS, TA and $\mathrm{pH}$; the other was stored at $-80^{\circ} \mathrm{C}$ for later analyses of total anthocyanins, tannins and total phenolics as described below.

\section{Berry chemical analyses}

\section{Total soluble solids, TA and pH}

Berry TSS, TA and pH were analysed on juice extracts for each of the 100 sample vines per site. Briefly, sample berries were gently crushed and the resulting juice was centrifuged at $1349 \times g$ for $5 \mathrm{~min}$. Total soluble solids were measured on a sample of the supernatant using a temperature compensating refractometer, results are given as g glucose equivalents $\mathrm{kg}^{-1}$ juice. 
Titratable acidity was determined by autotitrating $20 \mathrm{~mL}$ juice against $0.1 \mathrm{M} \mathrm{NaOH}$ to an endpoint $\mathrm{pH}$ 8.2, results are expressed as g tartaric acid equivalents $\mathrm{L}^{-1}$ juice. Juice $\mathrm{pH}$ was measured with $\mathrm{pH}$ electrodes.

\section{Anthocyanin, tannin and total phenolics}

Berry flavonoids (anthocyanin, tannin and total phenolics) were analysed in triplicates for each of the 100 samples vines per site. Samples of frozen whole berries were removed from a $-80^{\circ} \mathrm{C}$ freezer and further chilled in liquid nitrogen for a few minutes. The frozen berries were pulverised using a knife mill grinder (Grindomix GM200, Retsch®, GmbH) for 25 s at 10000 rpm. For anthocyanin determination, a subsample of the berry powder was extracted in $50 \%$ ethanol at 1:10 (w/v) sample to extractant ratio. The mixture was sonicated for $20 \mathrm{~min}$ to facilitate extraction of anthocyanins, after which the samples were centrifuged at $24784 \times g$ for 10 min. Aliquots of the supernatants were used for anthocyanin determination as described in Iland et $\mathrm{al}^{27}$. Total anthocyanin data are given as g malvidin-3-glucoside equivalents $\mathrm{kg}^{-1}$ berry fresh weight.

Tannins were determined on the aliquots of the extracts described above. The assay was based on the protein-tannin co-precipitation followed by reaction of the redissolved precipitate with $\mathrm{FeCl}_{3}$ as detailed in Harbertson et $\mathrm{al}^{28}$. Data are given as g catechin equivalents $\mathrm{kg}^{-1}$ berry fresh weight. Total iron-reactive phenolics were determined as in the tannin assay procedure by omitting the tannin-protein precipitation step. Results are given similarly to the tannins, in $g$ catechin equivalents kg-1 berry fresh weight. The flavonoids analyses were carried out at the Victorian Department of Primary Industries, Mildura.

\section{Data analysis}

Factor analysis and subsequently bivariate and partial correlation analyses were used to identify aspects of soil (physical and chemical) and vine (aerial imagery derived canopy size indices, 
crop size and berry size) properties that are associated with berry composition (anthocyanin, tannin, total phenolics, TA, TSS and $\mathrm{pH}$ ). The distributions of many of the variables across sites and years were multimodal; accordingly, data were analysed separately by site and year as well as for the vine and soil variables. Many of the variables were expressed in different measurement units and hence often had differing scales. To minimise scale effects, the factor analyses were performed on correlation matrices. Sometimes, what the extracted factors represented was not clear cut. To aid interpretation of extracted factors, orthogonal rotations (varimax procedure) of the factor solutions were carried out. For the extracted factors, factor scores corresponding to each observation (vine) were calculated using the loadings on each variable. The resulting scores were subsequently used for examining associations between components of berry composition and the extracted (latent) factors.

For the soil property variables, the extracted latent soil factors often appeared to show significant associations with both the vine-related variables and berry composition. When this occurred, partial correlation analysis was used to control for the influence of the latent factors on the vine property variables while examining if the extracted factors still retained significant associations with the berry composition variables. The analyses were performed using IBM ${ }^{\circledR}$ SPSS $^{\circledR}$ Statistics Version 21.0 (IBM Corp., Armonk, NY).

\section{RESULTS}

\section{Relationships between vine-related variables and berry flavonoids}

Three sets of factors (canopy size, crop size and berry size) were extracted from factor analysis of the eight vine-related variables (yield; berry weight; NDVI, PCD and vigour, each with and without mid-row vegetation). The first factor, accounting for between 45 and $72 \%$ of the total variance (depending on season and site), represented a measure of canopy size since it was primarily dominated by a composite of the vine size/density variables (Table 2). The factor weights on the vine size/density variables were all positive and equivalent. This canopy size 
factor had mostly significant negative associations with the concentrations of berry anthocyanin, tannin and total phenolics (Fig. 1).

The second and third factors respectively explained additional $13-20 \%$ and $3-17 \%$ of the total variance in the original variables. These two factors were single variable representations of either crop size or berry size (Table 2). While the variable that had the largest contribution to the second and third factors was the same across the five sites in a given year, there was a seasonal reversal: in 2006 and 2008, the second factor was dominated by crop size, while berry size was the largest contributing variable in 2007 (Table 2). This reversal of crop size and berry size loadings in 2007 vs. 2006 and 2008 reflected the seasonal yield patterns: across the three seasons, the yield patterns for all five sites had a V-shape, i.e. high in 2006 and 2008 and low in 2007 (Fig. S1, Goodwin et al. ${ }^{24}$ ). Both the second and third factors representing crop size or berry size had predominantly significant negative impacts on the berry flavonoids in all the years and sites (Fig. 1). Comparing across the three factors, in most cases, the berry flavonoids showed stronger associations with the crop and berry size factors than with the canopy size factor (Fig. 1).

\section{Relationships between vine-related variables and berry TA, TSS and pH}

The canopy size factor was mostly negatively associated with berry TSS and pH while it had a largely positive and significant correlation with TA (Fig. 1). Similarly, the crop and berry size factors showed high frequencies of significant negative associations with TSS and $\mathrm{pH}$, while their relations with TA were mostly positive (Fig. 1). Generally, the strength of associations of TSS, pH and TA with the crop and berry size factors were stronger than with the canopy size factor. This analysis resolved influences of canopy, crop and berry size factors and revealed 
that each factor had separate and mostly negative impacts on the berry components examined here except TA (Fig. 1).

\section{Influences of soil properties on vine-related variables and berry composition}

From the soil chemical and physical properties, depending on site, one or two factors that showed significant associations with the vine and/or berry composition variables were extracted (Table 3). On the bases of the absolute magnitudes of the factor loadings, the influential variables varied across sites and, occasionally, seasons (Table 3). For example, at the RV site, subsoil chemistry (i.e. $\mathrm{Cl}^{-}, \mathrm{EC}$ and $\mathrm{pH}$ at the $35-45 \mathrm{~cm}$ depth) were the most influential variables whereas at other sites such as the GS, profile-wide physico-chemical properties exerted influence. In other instances, e.g. the MD site, the influential variables in the 2006 season were dominated by the soil physical variables (subsoil bulk density/soil compaction and profile-wide sand content) whilst in the 2007 and 2008 seasons, EC and $\mathrm{Cl}^{-}$levels were influential (Table 3). At the GV and MD sites, a second factor representing soil compaction (bulk density) in the top $25 \mathrm{~cm}$ of the profile showed significant association with vine and/or berry composition attributes.

In spite of different sets of variables contributing to the extracted factors, there was a consistency with regard to the effects of the soil property variations represented by the extracted factors on both the vine-related variables and berry composition (Fig. 2). In most of the sites and years, the scores of the extracted factors were negatively correlated (often significantly) with the vine-related variables, i.e. berry weight, yield and vine size/density (Fig. 2). By contrast, the associations with berry composition were generally positive (Fig. 2). The associations and/or effects of the soil properties represented by the extracted factors on berry composition, except TA, were generally the reverse of the effects on the vine-related variables

(Fig. 2). Partial correlation analyses of berry composition variables and the extracted soil 
factors with berry weight, yield and vine size/density as control variables however showed that the soil chemical and physical properties had little effects on berry composition when their influences on vine size/density, yield and berry weight were accounted for (Table 4).

\section{DISCUSSION}

Canopy, crop, berry and soil influences on berry composition have long been of interest to viticulturists $^{4,6,8-10,13,14,29,30}$. Typically, however, these variables - especially of the vine components - are co-variant, which makes it difficult to differentiate their effects on berry composition. This work utilised comprehensive, multiyear datasets collected from five commercial Shiraz vineyards across southern Australia to identify vine and soil factors that have significant associations with, and by inference influences on, some of the key berry composition variables considered important for premium wine production. Collecting data from commercially operated vineyards across different regions inevitably introduces environmental (e.g., soil and climate) and management variations (e.g., shoot pruning and training systems, bud load, and irrigation frequency and volume) (Table 1). Account of such sources of variation is important when the aim is to identify mega-environment-scale drivers of berry composition: the focus here, however, is to understand vineyard-scale berry composition variation in relation to vine and soil variability. Even at a vineyard-scale, however, there can be considerable variations in soil physical and chemical properties as well as in vine-related characteristics such as canopy, yield and berry sizes (Supplementary Fig S1-S6). In traditional experiments, such variations would be disadvantage, as these would compromise detection of patterns. The spatially coupled soil and vine sampling methodology utilised here, which aimed at capturing vineyard-wide variation in soil and vine characteristics for each site, enabled de-convolution of the relative influences of vine and soil factors on berry composition. Further, despite the considerable differences in management 
and environmental conditions across the regions, the multivariate analyses results, discussed below, revealed commonality with regard to the patterns and strengths of association of berry composition variables with the vine and soil factors.

\section{Canopy, crop and berry size influences on concentrations of berry flavonoids}

The results from the five Shiraz vineyards showed that the concentrations of berry flavonoids were generally inversely related to the canopy, crop and berry sizes. Previous work also found inverse relations between concentrations of berry anthocyanins, tannins or total phenolics and remotely or proximally determined vine size measures ${ }^{8,10,31,32}$. From these earlier studies, however, it was not clear whether the reported associations were partly due to the co-variations of crop and berry sizes with canopy size. Similarly, there are several reports from thinning experiments that show significant negative effects of crop size on berry anthocyanin, tannin and total phenolics levels ${ }^{5,33,34}$, although Keller et al. $^{35}$ reported no effects in three varieties over a five year period whereas Cortell et al. ${ }^{30}$ found positive relationships between crop size as well as berry size and anthocyanin levels in Pinot Noir grapes. In many of these cases, changes in canopy and/or berry size that accompany crop-thinning treatments can confound attribution of the reported effects. Our results from the analyses of associations between berry flavonoids and the three orthogonal (uncorrelated) factors representing canopy, crop and berry size variables provide some insights. These revealed that canopy, crop and berry size were negatively correlated with concentrations of berry flavonoids, and further indicated that the strength of associations of berry composition were generally greater with measures of crop or berry size than with the canopy size.

The modest effect of canopy size, compared to crop and/or berry sizes, on flavonoids concentrations in this study is somewhat unexpected and contrasts to earlier findings of strong effects $^{8}$ and suggestions ${ }^{7}$. For example, Smart et al. ${ }^{7}$ posited that when management practices 
lead to increased yield and vine vigour, the associated "quality” reductions are due more to vigour modulation of microclimate than to an effect of increased yield. One possible reason for the modest influence of canopy size observed in our work is that the remotely sensed canopy size indices do not provide accurate measures of the actual canopy sizes in vertically shoot positioned canopies; however, this is unlikely as demonstrated in Proffitt and Malcolm ${ }^{36}$. Another factor may be the timing of remote sensing to canopy size estimation vis-à-vis vine phenology ${ }^{31}$. Lamb et al. ${ }^{31}$ showed that the strongest association between berry flavonoids at harvest (anthocyanin and phenolics) and remotely sensed canopy size measures such as NDVI occurred when remote sensing was done at veraison, which was when remote sensing data were acquired for all sites and years, hence unlikely to explain the weak relations observed here.

Although the analyses presented here revealed consistent and strong apparent influence of crop size on berry flavonoids, the mechanism is not clear. Concentrations of some of the flavonoids (especially anthocyanin) are functions of the state of berry ripening ${ }^{21,35,37}$. It is thus possible that crop size-induced ripening lag and/or shifts in source-sink relations ${ }^{38,39}$ partly account for the reductions in flavonoid levels with increasing crop size.

In terms of the negative influence of berry size on flavonoids, the response of Shiraz anthocyanin from this study was similar to that of Cabernet Sauvignon ${ }^{6}$ in which anthocyanin accumulation lagged the gain in berry weight with increasing berry size, indicating a dilution effect. The tannin response to berry size may also be partly a dilution effect. For example, tannin concentrations generally peak before veraison or in the early phase of berry ripening ${ }^{28,40-}$ ${ }^{42}$. On the other hand, a significant component of the final berry mass accrues post-veraison ${ }^{43,44}$, and thus some of the negative association between tannin concentration and berry size may be a dilution response.

The literature ${ }^{8,16-18,45}$ on the effect of shading/light exposure or vigour on berry anthocyanin concentrations shows inconsistent findings. Our results (Fig. 2) which show a stronger 
association of anthocyanin levels with crop and berry size than with canopy size hint to some factor(s) that may contribute to the variable responses and thus are relevant from an experimental design perspective. That is, some of the apparently variable response of anthocyanin concentrations to shading may have resulted from variations in crop and/or berry size - a consistent effect is likely to be observed when crop size and berry size are made comparable between shading/exposure treatments.

The consistency of results from five climatically different sites across three seasons suggests that, in Shiraz vines, management aimed at regulating berry and crop sizes may potentially offer a greater means of influencing berry flavonoid concentrations than canopy management. However, given the inverse relationships between flavonoid concentrations and crop size, a consideration of the trade-offs is also pertinent. An alternative approach is maturity based harvesting. The trials for this work were carried out in commercial vineyards, which necessitated harvesting of berry samples on the same day closer to each vineyard's commercial harvest date. Inevitably, same day sampling of berries across a block in the presence of variation in crop and canopy sizes (or variable source-to-sink ratios) leads to variation in berry ripening. In situations where there are sufficiently large areas with discrete spatial patterns in vigour and yield (and thus ripening), selective harvesting according to ripening may offer alternative management opportunity, i.e. without a yield versus “quality” trade-off, provided economic considerations warrant it.

Vine-related variables and berry TSS, $p H$ and TA

With few exceptions, the associations of berry TSS, $\mathrm{pH}$ and TA with canopy, crop and berry size factors conformed to the expected trends: TA levels dropped with reductions in canopy and crop sizes while the opposite trends held for TSS and $\mathrm{pH}$. Influences of berry size were less clear-cut except for the Murray-Darling site where there were consistent trends (similar to those 
of canopy and crop size) across the three vintages (Fig. 1). While the qualitative patterns described above are generally similar to reports elsewhere ${ }^{15,30,37}$, the unexpected outcome here - as was also the case for berry flavonoids - was the stronger influence of crop size on TSS, pH and TA than canopy size. Since berry samples were collected on the same day for each site, the negative influence of crop size on TSS may indicate delayed ripening due to low source capacity relative to sink size as crop size increased as observed in crop thinning experiments 4,5 . An increase in canopy size, other things being equal, from source capacity point of view would be expected to have a positive influence on TSS levels although our results indicate otherwise. This may indicate increasing self-shading as canopy size increases, in which case leaves from the shaded interior of the canopy transition to partial heterotrophy and hence compete for assimilate against ripening berries thereby slowing berry TSS accumulation rates.

How canopy and crop size positively influence berry TA is not clear, although such observations are frequently reported. Tartrate and malate are major contributors to $\mathrm{TA}^{46,47}$. The synthesis of TA is thought to be essentially complete at veraison ${ }^{47,48}$, malic acid also peaks at veraison $^{47}$. Post-veraison, while TA per berry remains relatively stable, malic acid is strongly metabolised $^{46,47}$ serving as a carbon skeleton or a substrate for multiple metabolic roles including berry respiration ${ }^{49}$. In this respect, the positive influence of canopy size on TA levels may reflect partly moderation of the bunch-zone or berry temperature and hence reduced berry respiration rate ${ }^{50}$ and partly due to a ripening delay effect. Delayed ripening may also partly account for the crop size influence on TA.

\section{Soil properties and berry composition}

The initial analysis of the relationships between berry composition and factor scores derived from the soil physical and chemical properties showed significant correlations across the five sites. This is consistent with reports of several studies which indicate a soil effect on berry 
composition $^{9,12}$ although Pereira et al. ${ }^{13}$ found no apparent effects. Jackson and Lombard ${ }^{1}$ lamented that while there is a general belief that soil affects berry composition, this view is largely based on a comparison of results from different locations, which make it difficult to “disentangle” a soil effect from possible contributions of many other factors. This is a pertinent point since soil type or properties do affect some key vine attributes (Fig. 3). As discussed in the previous section, vine attributes have significant associations with berry composition. When the effects of soil properties on vine attributes are accounted for, it emerges that the apparent effect of soil on berry composition is either modest or effectively non-existent. This indicates that the soil "effect” is indirect, being mediated via its influence on vine attributes (canopy, crop and berry sizes). Indeed, a cursory examination of many of the reported soil effects cited above indicates a similar operational mechanism as found in this work. Nevertheless, this does not preclude an effect of soil factors on aspects of berry composition that are directly derived from the soils such as mineral nutrient composition ${ }^{9,51,52}$.

\section{CONCLUSION}

The extensive and unique nature of the data used here (where berry composition of individual vines along with a comprehensive characterisation of the respective vines properties with respect to canopy, crop and berry sizes as well as their root zone environment) enabled a differentiation of the influences of these variables on some of the basic components of berry composition. Based on the extensive Shiraz dataset used in this work, it is concluded that concentrations of most of the berry attributes considered here are more closely related to, and possibly influenced by, crop and berry size than canopy size. Further work evaluating the generality of these observations is warranted. This is relevant given the greater attention given to canopy than to crop management influences on berry composition. The analyses presented in this work also revealed that most of the apparent effects of the soil physical and chemical 
properties on berry composition were indirect, mediated via either canopy size, crop size and/or berry size. That is, the apparent effect of soil physical and chemical properties on berry composition was generally contingent on there being an effect on one or more of the vine properties.

\section{ACKNOWLEDGEMENTS}

We thank vineyard owners for supporting the research by allowing their vineyards to be used for this study. We also thank D. Kelly, M. Mazza, N. Baker, J. Hornbuckle, D. Smith, D. Mowat, A. Simson, W. Sessions and J. Kirby for technical assistance and data collection. The manuscript benefited from comments of three anonymous reviewers. This work was supported by the Australian Grape and Wine Research and Development Corporation (grant number DPI04/04).

\section{REFERENCES}

1 Jackson DI and Lombard PB, Environmental and management practices affecting grape composition and wine quality - a review. Am J Enol Vitic 44: 409-430 (1993).

2 Holt HE, Francis IL, Field J, Herderich MJ and Iland PG, Relationships between berry size, berry phenolic composition and wine quality scores for Cabernet Sauvignon (Vitis Vinifera L.) from different pruning treatments and different vintages. Austr J Grape Wine Res 14: 191-202 (2008). 
3 Downey MO, Dokoozlian NK and Krstic MP, Cultural practice and environmental impacts on the flavonoid composition of grapes and wine: a review of recent research. Am J Enol Vitic 57: 257-268 (2006).

4 Bravdo B, Hepner Y, Loinger C, Cohen S and Tabacman H, Effect of crop level and crop load on growth, yield, must and wine composition, and quality of Cabernet Sauvignon. Am J Enol Vitic 36: 125-131 (1985).

5 Gatti M, Bernizzoni F, Civardi S and Poni S, Effects of cluster thinning and preflowering leaf removal on growth and grape composition in cv. Sangiovese. Am J Enol Vitic 63: 325-332 (2012).

6 Roby G, Harbertson JF, Adams DA and Matthews MA, Berry size and vine water deficits as factors in winegrape composition: anthocyanins and tannins. Aust J Grape Wine Res 10: 100-107 (2004).

7 Smart RE, Robinson JB, Due GR and Brien CJ, Canopy microclimate modification for the cultivar Shiraz. II. Effects on must and wine composition. Vitis 24: 119-128 (1985a).

8 Cortell J, Halbleib M, Gallagher AV, Righetti TL and Kennedy JA Influence of vine vigour on grape (Vitis vinifera L. Cv. Pinot Noir) and wine proanthocyanidins. J Agric Food Chem 53: 5798-5808 (2005).

9 Reynolds AG, Senchuk IV, van der Reest C and de Savigny C Use of GPS and GIS for elucidation of the basis for terroir: spatial variation in an Ontario Riesling vineyard. Am J Enol Vitic 58: 145-162 (2007).

10 Hall A, Lamb DW, Holzapfel, BP and Louis JP, Within-season temporal variation in correlations between vineyard canopy and winegrape composition and yield. Prec Agric 12: 103-117 (2010).

This article is protected by copyright. All rights reserved 
11 Choné X, Van Leeuwen C, Chéry P and Ribéreau-Gayon P, Terroir influence on water status and nitrogen status of non-irrigated Cabernet Sauvignon (Vitis vinifera). Vegetative development, must and wine composition (example of a Medoc top estate vineyard, St Julien area, Bordeaux, 1997). S Afric J Enol Vitic 22: 8-15 (2001).

12 van Leeuwen C, Friant P, Choné X, Tregoat O, Koundouras S, and Dubourdieu D, Influence of climate, soil, and cultivar on terroir. Am J Enol Vitic 55: 207-217 (2004).

13 Pereira GE, Gaudillere JP, van Leeuwen C, Hilbert G, Maucourt M, Deborde C, Moing A and Rolin D, H-NMR metabolite fingerprints of grape berry: comparison of vintage and soil effects in Bordeaux grapevine growing areas. Anal Chim Acta 563: 346-352 (2006a).

14 De Adres-de Prado R, Yuste-Rojas M, Sort X, Andrés-Lacueva C, Torres M and Lamuela-Raventós RM, Effect of soil type on wines produced from Vitis vinifera L. cv. Grenache in commercial vineyards. J Agric Food Chem 55: 779-786 (2007).

15 Smart RE, Robinson JB, Due GR and Brien CJ, Canopy microclimate modification for the cultivar Shiraz. I. Definition of canopy microclimate. Vitis 24: 17-31 (1985b).

16 Bergqvist J, Dokoozlian NK and Ebisuda N, Sunlight exposure and temperature effects on berry growth and composition of Cabernet Sauvignon and Grenache in the central San Joaquin Valley of California. Am J Enol Vitic 52: 1-7 (2001).

17 Spayd SE, Tarara JM, Mee DL and Ferguson J, Separation of sunlight and temperature effects on the composition of Vitis vinifera cv, Merlot berries. Am J Enol Vitic 53: 171-182 (2002).

18 Downey MO, Harvey JS and Robinson SP, The effect of bunch shading on berry development and flavonoid accumulation in Shiraz grapes. Aust J Grape Wine Res 10: 55-73 (2004).

This article is protected by copyright. All rights reserved 
19 Pereira GE, Gaudillere JP, Pieri P, Hilber G, Maucourt M, Deborde C, Moing A and Rolin D, Microclimate influence on mineral and metabolic profiles of grape berries. $J$ Agric Food Chem 54: 6765-6775 (2006b).

20 Kliewer WM, Influence of temperature, solar radiation and nitrogen on coloration and composition of Emperor grapes. Am J Enol Vitic 28: 96-103 (1977).

21 Keller M and Hrazdina G, Interaction of nitrogen availability during bloom and light intensity during veraison. II. Effects on anthocyanin and phenolic development during grape ripening. Am J Enol Vitic 49: 341-349 (1998).

22 Barnes MB, Corell RL and Lanyon DM, Selecting sample vines to capture spread of soil/vine characteristics, in Proceedings of the 13th Australian Wine Industry Technical Conference, Glen Osmond, South Australia, p. 318 (2007).

23 Goodwin I, McClymont L, Lanyon D, Zerihun A, Hornbuckle J, Gibberd M, Mowat D, Smith D, Barnes M, Correl, R and Wheaton A, Managing Soil and Water to Target Quality and Reduce Environmental Impact: Final report to Grape and Wine Research and Development Corporation Project Number: DPI 04/04. http://www.gwrdc.com.au/wp-content/uploads/2012/09/DPI-04-04-smaller.pdf [accessed on 02 August 2013] (2009).

24 Zerihun A, Lanyon DM and Gibberd M, Vine vigour effects on leaf gas exchange and resource utilisation. Aust J Grape Wine Res 16: 237-242 (2009).

25 Janik LJ, Merry RH, Forrester ST, Lanyon DM and Rawson A, Rapid prediction of soil water retention using mid infrared spectroscopy. Soil Sci Soc Am J 71: 507-514 (2007).

26 Keller M, The Science of Grapevines: Anatomy and Physiology. Academic Press, New York, (2010). 
27 Iland P, Bruer N, Edwards G, Weeks S and Wilkes E, Chemical Analysis of Grapes and Wine: Techniques and Concepts. Adelaide: Patrick Iland Wine Promotions Pty Ltd (2004).

28 Harbertson, JF, Kennedy JA and Adams DO, Tannin in skins and seeds of Cabernet Sauvignon, Syrah, and Pinot Noir berries during ripening. Am J Enol Vitic 53: 54-59 (2002).

29 Freeman BM and Kliewer WM, Effect of irrigation, crop level and potassium fertilisation on Carignane vines. 2. Grape and wine quality. Am J Enol Vitic 34: 197207 (1983).

30 Cortell J, Halbleib M, Gallagher AV, Righetti TL and Kennedy JA, Influence of vine vigor on grape (Vitis vinifera L. Cv. Pinot Noir) anthocyanins. 1. Anthocyanin concentration and composition in fruit. J Agric Food Chem 55: 6575-6584 (2007).

31 Lamb DW, Weedon MM and Bramley RGV, Using remote sensing to predict grape phenolics and colour at harvest in a Cabernet Sauvignon vineyard: timing observations against vine phenology and optimising image resolution. Aust J Grape Wine Res10: 46-54 (2004).

32 Tadaguila J, Martinez de Toda F, Poni S and Diago MP, Impact of early leaf removal on yield and fruit and wine composition of Vitis viniefa L. Graciano and Carignan. Am J Enol Vitic 61: 372-381 (2010).

33 Petrie PR and Clingeleffer PR, Crop thinning (hand versus mechanical), grape maturity and anthocyanin concentration: outcomes from irrigated Cabernet Sauvignon (Vitis vinifera L.) in a warm climate. Aust J Grape Wine Res 12: 21-29 (2006).

34 Prajitna A, Dami IE, Steiner TE, Ferree DC, Scheerens JC and Schwartz SJ Influence of cluster thinning on phenolic composition, resveratrol, and antioxidant capacity in Chambourcin wine. Am J Enol Vitic 58: 346-350 (2007).

This article is protected by copyright. All rights reserved 
35 Keller M, Mills LJ, Wample RL and Spayd SE, Cluster thinning effects on three deficitirrigated Vitis vinifera cultivars. Am J Enol Vitic 56: 91-103 (2005).

36 Proffitt $\mathrm{T}$ and Malcolm A, Zonal vineyard management through airborne remote sensing. Austr NZ Grapegrower Winemaker 502: 22-27 (2005).

37 Esteban MA, Villanueva MJ and Lissarrague JR, Effect of irrigation on changes in the anthocyanin composition of the skin of cv Tempranillo (Vitis vinifera L.) grape berries during ripening. J Sci Food Agric 81: 409-420 (2001).

38 Kliewer WM and Weaver RJ, Effect of crop level and leaf area on growth, composition, and coloration of ‘Tokay’ grapes. Am J Enol Vitic 22: 172-177 (1971).

39 Kliewer WM and Dokoozlian NK, Leaf area/crop weight ratios of grapevines: influence on fruit composition and wine quality. Am J Enol Vitic 56: 170-181 (2005).

40 Kennedy JA, Mathews MA and Waterhouse AL, Effect of maturity and vine water status on grape skin and wine flavonoids. Am J Enol Vitic 53: 268-274 (2002).

41 Downey MO, Harvey JS and Robinson SP, Analysis of tannins in seeds and skins of Shiraz grapes throughout berry development. Austr J Grape Wine Res 9: 15-27 (2003).

42 Bindon KA and Kennedy JA, Ripening-induced changes in grape skin proanthocyanidins modify their interaction with cell walls. J Agric Food Chem 59: 2696-2707 (2011).

43 Coomb BG, Research on development and ripening of the grape berry. Am J Enol Vitic 43: $101-110$ (1992).

44 Kennedy JA, Mathews MA and Waterhouse AL, Changes in grape seed polyphenols during fruit ripening. Phytochem 55: 77-85 (2000).

45 Smart RE, Smith SM and Winchester RV, Light quality and quantity effects on fruit ripening on Cabernet Sauvignon. Am J Enol Vitic 39: 250-258 (1988).

This article is protected by copyright. All rights reserved 
46 Philip T and Ruykendall JR, Changes in titratable acidity, ${ }^{\circ} \mathrm{Brix}, \mathrm{pH}$, potassium content, malate and tartrate during berry development of Thompson seedless grapes. Journal of Food Science 38: 874-876 (1973).

47 Iland PG and Coombe BG, Malate, Tartrate, potassium, and sodium in flesh and skin of Shiraz grapes during ripening: concentration and compartmentation. Am J Enol Vitic 39: $71-76$ (1988).

48 DeBolt S, Cook DR and Ford CM, L-Tartaric acid synthesis from vitamin C in higher plants. Proceedings of the National Academy of Sciences, USA 103: 5608-5613 (2006).

49 Sweetman C, DeLuc L, Cramer G, Ford C and Soole K, Regulation of malate metabolism in grape berry and other developing fruits. Phytochem 70: 1329-1344 2009).

50 Buttrose MS, Hale CR and Kliewer WM, Effect of temperature on the composition of Cabernet Sauvignon berries. Am J Enol Vitic 22: 71-75 (1971).

51 Zou J-F, Peng Z-X, Du H-J, Duan C-Q, Reeves MJ and Pan Q-H, Elemental patterns of wines, grapes, and vineyard soils from Chinese wine-producing regions and their association. Am J Enol Vitic 63: 232-2240 (2012).

52 Holzapfel BP and Treeby MT, Effects of timing and rate of N supply on leaf nitrogen status, grape yield and juice composition from Shiraz grapevines grafted to one of three different rootstocks. Aust J Grape Wine Res 13: 14-22 (2007).

This article is protected by copyright. All rights reserved 
Fig 1. Correlations of components of berry composition with vine property related factor solutions. Top panel: berry flavonoids - for each site, the bars within each factor structure from left to right are anthocyanin, tannin and total (iron reactive) phenolics. Bottom panel: berry ripening indicators - for each site, the bars within each factor structure refer to TSS, $\mathrm{pH}$ and TA. The horizontal dashed lines are the critical values at the 5\% probability level.

Correlations (bars) extending above or below the dashed lines are significant $(\mathrm{p}<0.05)$.

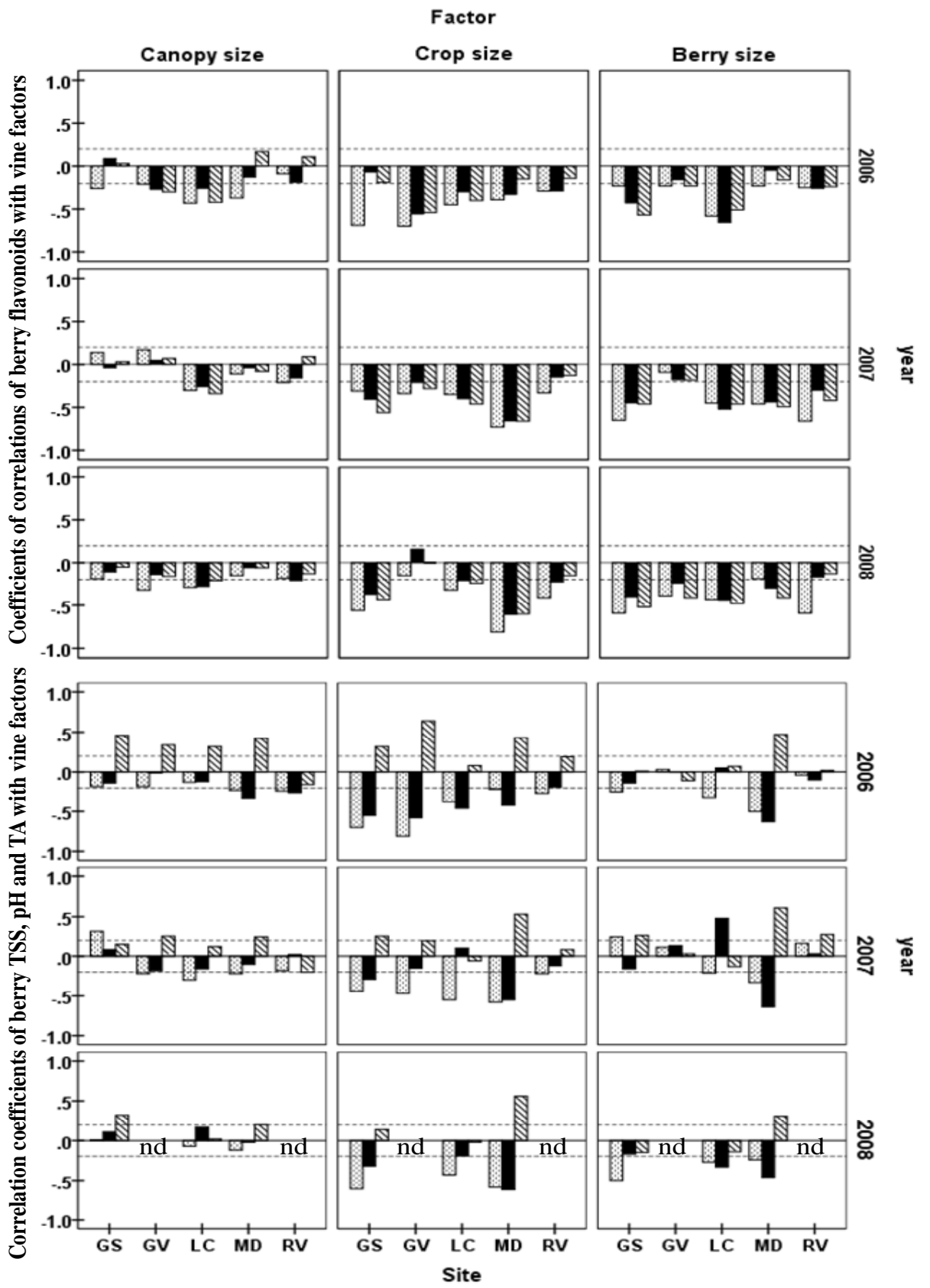

This article is protected by copyright. All rights reserved 
Fig 2. Correlations of components of berry composition with factors extracted from soil chemical and physical properties over three vintages. The horizontal dashed lines are the critical values at the $5 \%$ probability level. Correlations (bars) extending above or below the dashed lines are significant at $\mathrm{p}<0.05$. TSS, total soluble solids; TA, Titratable acidity; Anth, anthocyanin;Tan, tannin; TP, total phenolics; Yldm2, yield.m² ${ }^{-2}$; Berwt, berry weight; the vegetation indices are as defined in Table 2.
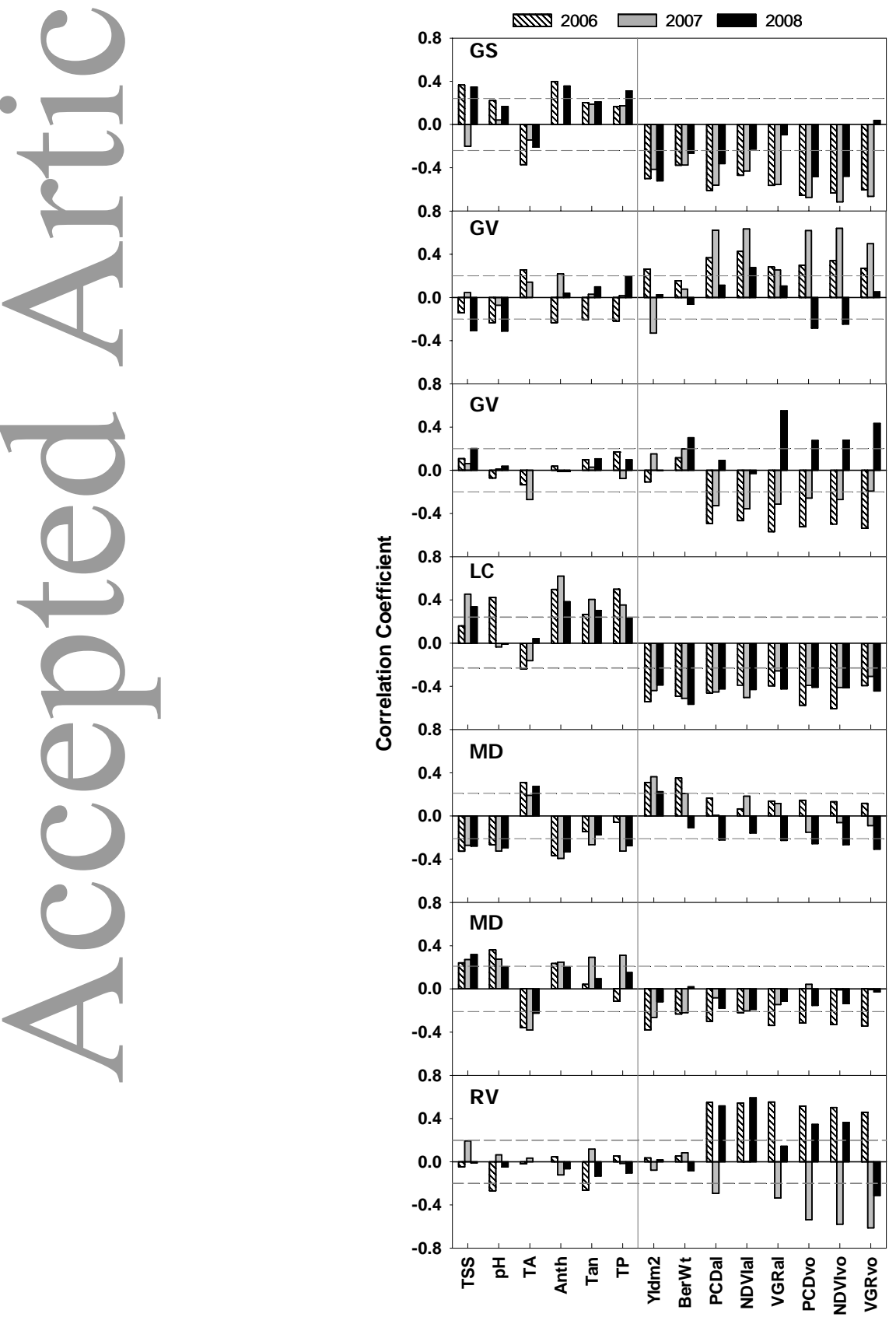

This article is protected by copyright. All rights reserved 
Table 1. Descriptions of the study vineyards. The climate data, from onsite weather stations, are averages for the three (2005-2008) seasons of study. ${ }^{\dagger}$ The 3-yr mean annual rainfall and reference crop evapotranspiration (ETo) were calculated from leaf-fall to leaf fall. Median bud load (number. $\mathrm{m}^{-1}$ cordon). ${ }^{\S}$ Average ( $\mathrm{n}=100$ cores, mid-infrared spectroscopy predicted textural composition (\%) of the top $80 \mathrm{~cm}$ of the soil profile: sand, clay and silt, respectively.

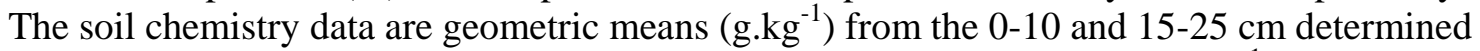
for 40 of the 100 cores for each site. CEC, cation exchange capacity $\left(\mathrm{cmol}^{+} . \mathrm{kg}^{-1}\right)$; ESP, exchangeable sodium percentage.

\begin{tabular}{|c|c|c|c|c|c|c|}
\hline \multirow{2}{*}{\multicolumn{2}{|c|}{ Descriptor }} & \multicolumn{5}{|c|}{ Geographic Indications } \\
\hline & & GS & GV & LC & MD & RV \\
\hline \multicolumn{2}{|c|}{$\begin{array}{l}\text { Location, } \\
{ }^{\circ} \mathrm{S},{ }^{\circ} \mathrm{E}\end{array}$} & $34.39,116.95$ & confidential & $35.33,138.98$ & $34.42,142.28$ & $34.25,146.21$ \\
\hline \multicolumn{2}{|c|}{$\begin{array}{l}\text { Elevation, } \\
\text { m a.s.l. }\end{array}$} & 262 & 124 & 15 & 46 & 129 \\
\hline \multicolumn{2}{|c|}{$\begin{array}{l}\text { Year } \\
\text { planted }\end{array}$} & 1997 & $1999 / 2000$ & 1992 & 1994 & 1998 \\
\hline \multicolumn{2}{|c|}{$\begin{array}{l}\text { Block } \\
\text { size, ha }\end{array}$} & 6.8 & 16.0 & 6.8 & 6.4 & 12.3 \\
\hline & $\begin{array}{l}\text { Root } \\
\text { stoc } \\
\mathrm{k}\end{array}$ & own-root & Schwarzmann & own-root & Schwarzmann & own-root \\
\hline & $\begin{array}{l}\text { Row } \\
\text { (spa } \\
\text { cing } \\
\text { and } \\
\text { orie } \\
\text { ntati } \\
\text { on) }\end{array}$ & $\begin{array}{r}3.6 \times 1.8 \\
E-W\end{array}$ & $\begin{array}{r}3.0 \times 1.8 \\
N-S\end{array}$ & $\begin{array}{r}3.0 \times 1.8 \\
N-S\end{array}$ & $\begin{array}{r}3.0 \times 2.4 \\
E-W\end{array}$ & $\begin{array}{l}3.3 \times 1.8 \\
\mathrm{NE}-\mathrm{SW}\end{array}$ \\
\hline & $\begin{array}{l}\text { Prun } \\
\text { ing } \\
\text { met } \\
\text { hod }\end{array}$ & $\begin{array}{r}\text { Hand, 2-bud } \\
\text { spurs }\end{array}$ & $\begin{array}{r}\text { Hand, 2-bud } \\
\text { spurs }\end{array}$ & $\begin{array}{r}\text { Hand, 2-bud } \\
\text { spurs }\end{array}$ & $\begin{array}{r}\text { Mechanically } \\
\text { hedge-pruned }\end{array}$ & $\begin{array}{r}\text { Mechanically } \\
\text { pruned, and hand } \\
\text { clean-up } \sim 4 \text {-bud } \\
\text { spurs }\end{array}$ \\
\hline & $\begin{array}{l}\text { Bud } \\
\text { load }\end{array}$ & 16 & 24 & 12 & 57 & 20 \\
\hline $\begin{array}{l}\text { Man } \\
\text { age } \\
\text { men } \\
t\end{array}$ & $\begin{array}{l}\text { Trai } \\
\text { ning } \\
\text { syst } \\
\text { em, } \\
\text { cord } \\
\text { on } \\
\text { heig } \\
\text { ht, } \\
\text { folia } \\
\text { ge } \\
\text { wire } \\
\text { s } \\
\text { posit } \\
\text { ion }\end{array}$ & $\begin{array}{l}\text { VSP, bilateral } \\
\text { cordons, } 0.9 \mathrm{~m} \text {, } \\
+0.3 \mathrm{~m},+0.6 \mathrm{~m}\end{array}$ & $\begin{array}{r}\text { VSP, bilateral } \\
\text { cordons, } 1.15 \mathrm{~m} \text {, } \\
+0.45 \mathrm{~m},+0.65 \mathrm{~m}\end{array}$ & $\begin{array}{r}\text { Foliage wires } \\
\text { only, bilateral } \\
\text { cordons, } 1 \mathrm{~m}, \\
+0.5 \mathrm{~m}\end{array}$ & $\begin{array}{r}2 \text { bilateral } \\
\text { cordons, } \\
\text { vertically } \\
\text { separated }\end{array}$ & $\begin{array}{l}2 \text { bilateral cordons, } \\
\text { vertically separated }\end{array}$ \\
\hline & $\begin{array}{l}\text { mea } \\
\mathrm{n} \\
\text { irrig } \\
\text { atio } \\
\mathrm{n}, \\
\mathrm{mm}\end{array}$ & 35 & 266 & 167 & 463 & 471 \\
\hline
\end{tabular}

This article is protected by copyright. All rights reserved 


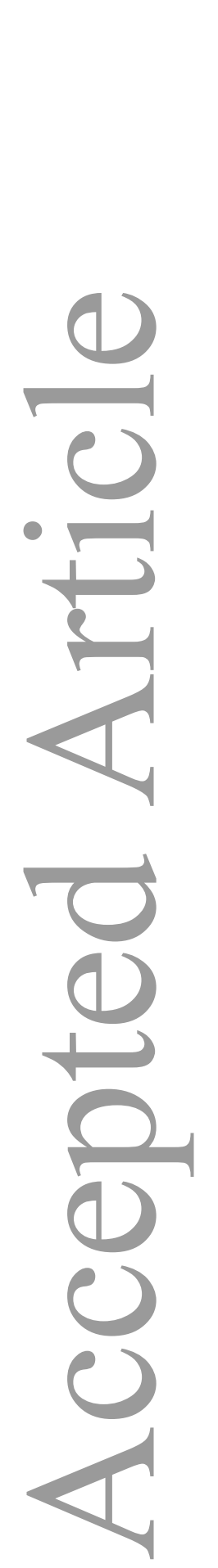

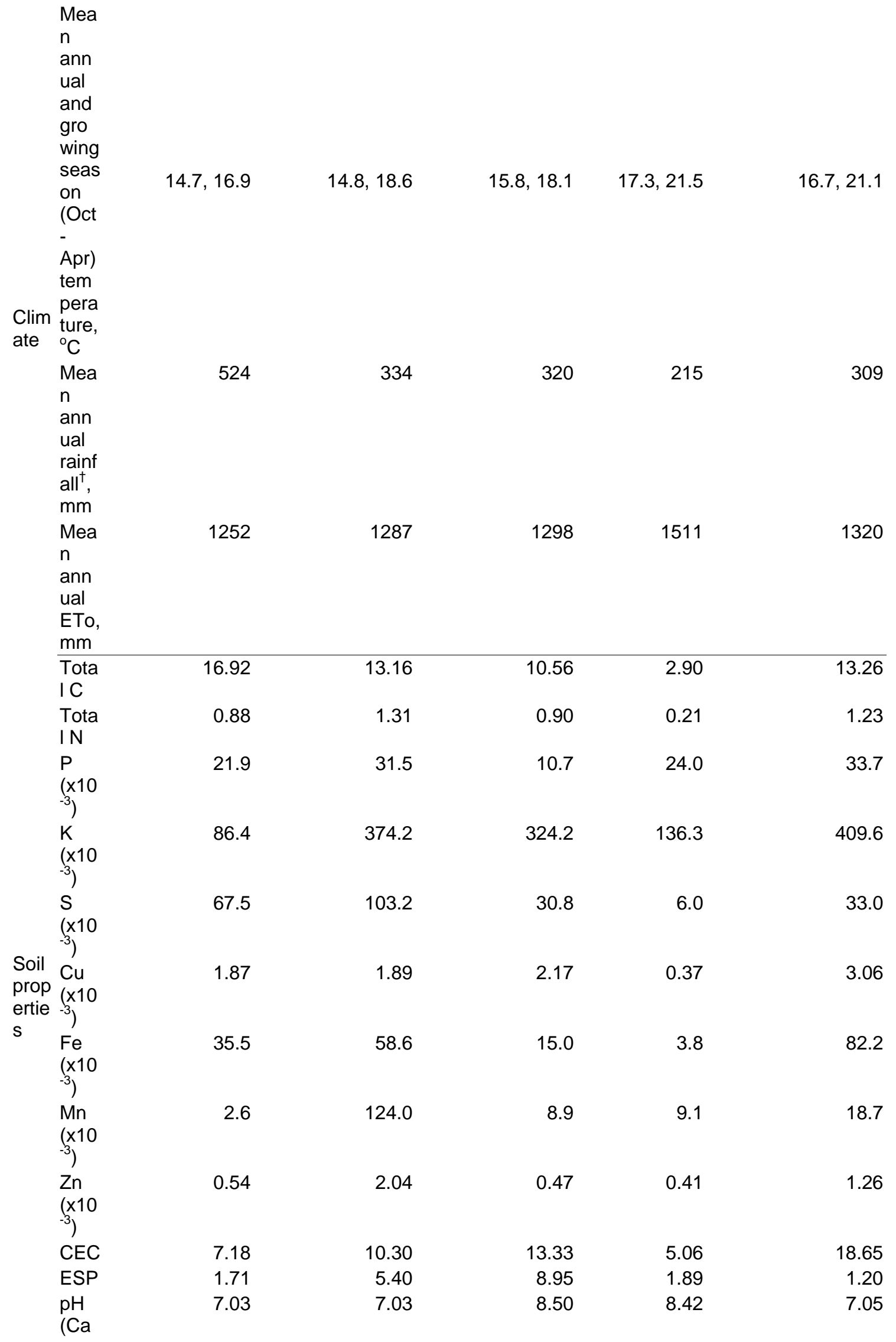

This article is protected by copyright. All rights reserved 


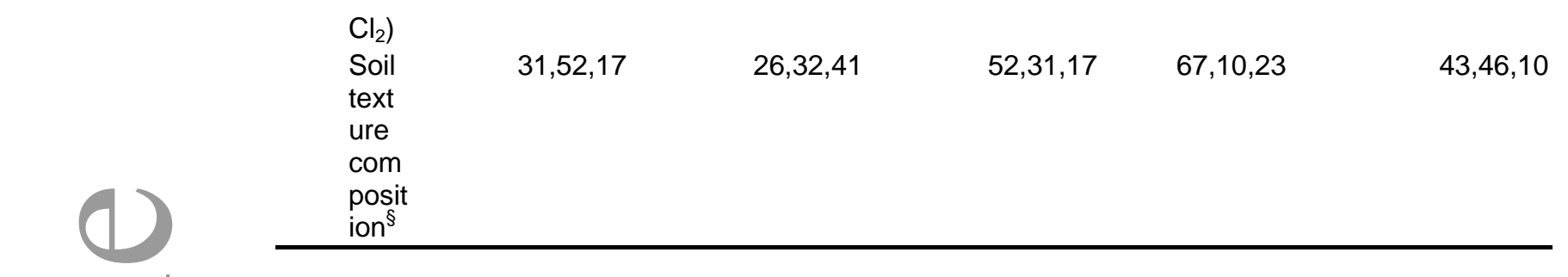

This article is protected by copyright. All rights reserved 
Table 2. The loadings of variables on three latent factors extracted from factor analysis of the vine property variables. The extracted latent factors are labelled as providing measures of canopy, crop or berry sizes based on the variables that dominated each latent factor as shown in boldface. For the remotely sensed canopy size/density indices, the suffix al means the imagery index includes vine and inter-row vegetation, whereas _vo means the index is based on vine only pixels. The percentages refer to the proportion of variance accounted for by each extracted factor.

\begin{tabular}{|c|c|c|c|c|c|c|c|c|c|c|}
\hline & \multirow[t]{2}{*}{ year } & \multicolumn{3}{|c|}{2006} & \multicolumn{3}{|c|}{2007} & \multicolumn{3}{|c|}{2008} \\
\hline & & canopy & crop & berry & canopy & berry & crop & canopy & crop & berry \\
\hline Site & variables & $60.7 \%$ & $17.9 \%$ & $14.6 \%$ & $54.8 \%$ & $20.4 \%$ & $16.7 \%$ & $57.3 \%$ & $20.2 \%$ & $14.9 \%$ \\
\hline \multirow{8}{*}{ GS } & Yield $/ \mathrm{m}^{2}$ & 0.34 & 0.89 & 0.22 & 0.28 & 0.27 & 0.92 & 0.14 & 0.82 & 0.43 \\
\hline & Berry Wt & 0.20 & 0.19 & 0.96 & 0.25 & 0.94 & 0.25 & 0.21 & 0.32 & 0.92 \\
\hline & PCD_al & 0.85 & 0.41 & 0.21 & 0.82 & 0.41 & 0.23 & 0.85 & 0.46 & 0.18 \\
\hline & NDVI_al & 0.78 & 0.43 & 0.22 & 0.61 & 0.51 & 0.20 & 0.86 & 0.38 & 0.14 \\
\hline & VGR_al & 0.88 & 0.31 & 0.21 & 0.86 & 0.30 & 0.19 & 0.92 & 0.05 & 0.16 \\
\hline & PCD_vo & 0.93 & 0.28 & 0.16 & 0.93 & 0.27 & 0.24 & 0.82 & 0.49 & 0.20 \\
\hline & NDVI_vo & 0.93 & 0.25 & 0.15 & 0.92 & 0.25 & 0.24 & 0.82 & 0.48 & 0.20 \\
\hline & VGR_vo & 0.93 & 0.12 & 0.13 & 0.93 & 0.11 & 0.17 & 0.93 & -0.07 & 0.11 \\
\hline \multirow{9}{*}{ GV } & & $67.8 \%$ & $13.9 \%$ & $2.9 \%$ & $64.9 \%$ & $13.8 \%$ & $13.1 \%$ & $46.5 \%$ & $15.5 \%$ & $13.4 \%$ \\
\hline & Yield/m² & 0.27 & 0.94 & 0.20 & -0.13 & 0.09 & 0.99 & 0.18 & 0.10 & 0.98 \\
\hline & Berry Wt & 0.05 & 0.17 & 0.98 & -0.01 & 0.97 & 0.07 & 0.02 & 0.99 & 0.13 \\
\hline & PCD_al & 0.96 & 0.17 & 0.09 & 0.97 & -0.03 & -0.10 & 0.90 & -0.03 & 0.13 \\
\hline & NDVI_al & 0.94 & 0.13 & 0.09 & 0.97 & -0.03 & -0.11 & 0.76 & -0.11 & 0.09 \\
\hline & VGR_al & 0.95 & 0.14 & 0.05 & 0.69 & -0.39 & -0.16 & 0.45 & 0.34 & -0.07 \\
\hline & PCD_vo & 0.95 & 0.22 & 0.05 & 0.99 & 0.01 & -0.09 & 0.91 & 0.15 & 0.17 \\
\hline & NDVI_vo & 0.95 & 0.22 & 0.04 & 0.98 & 0.03 & -0.09 & 0.92 & 0.15 & 0.18 \\
\hline & VGR_vo & 0.92 & 0.17 & -0.02 & 0.93 & -0.09 & -0.06 & 0.64 & 0.28 & 0.05 \\
\hline \multirow{9}{*}{$\mathrm{LC}$} & & $60.6 \%$ & $18.7 \%$ & $14.6 \%$ & $53.8 \%$ & $18.9 \%$ & $13.5 \%$ & $55.3 \%$ & $15.7 \%$ & $14.6 \%$ \\
\hline & Yield/m² & 0.24 & 0.92 & 0.27 & 0.37 & 0.41 & 0.84 & 0.27 & 0.92 & 0.28 \\
\hline & Berry Wt & 0.40 & 0.37 & 0.83 & 0.23 & 0.93 & 0.30 & 0.26 & 0.32 & 0.91 \\
\hline & PCD_al & 0.92 & 0.25 & 0.24 & 0.90 & 0.34 & 0.24 & 0.94 & 0.23 & 0.20 \\
\hline & NDVI_al & 0.91 & 0.12 & 0.24 & 0.86 & 0.34 & 0.21 & 0.92 & 0.22 & 0.21 \\
\hline & VGR_al & 0.90 & 0.18 & 0.31 & 0.56 & 0.00 & 0.13 & 0.75 & 0.32 & 0.25 \\
\hline & PCD_vo & 0.84 & 0.43 & 0.21 & 0.90 & 0.34 & 0.25 & 0.95 & 0.22 & 0.16 \\
\hline & NDVI_vo & 0.84 & 0.41 & 0.23 & 0.90 & 0.35 & 0.24 & 0.95 & 0.22 & 0.16 \\
\hline & VGR_vo & 0.86 & 0.23 & 0.31 & 0.80 & 0.14 & 0.24 & 0.45 & 0.01 & 0.25 \\
\hline \multirow{9}{*}{ MD } & & $65.7 \%$ & $14.6 \%$ & $14.1 \%$ & $60.3 \%$ & $18.6 \%$ & $16.0 \%$ & $65.9 \%$ & $15.6 \%$ & $13.4 \%$ \\
\hline & Yield/m² & 0.22 & 0.92 & 0.28 & 0.03 & 0.29 & 0.94 & 0.05 & 0.93 & 0.26 \\
\hline & Berry Wt & 0.12 & 0.24 & 0.95 & 0.19 & 0.91 & 0.32 & 0.24 & 0.29 & 0.92 \\
\hline & PCD_al & 0.94 & 0.28 & 0.12 & 0.90 & 0.30 & 0.25 & 0.95 & 0.21 & 0.17 \\
\hline & NDVI_al & 0.85 & 0.33 & 0.03 & 0.68 & 0.51 & 0.42 & 0.86 & 0.39 & 0.11 \\
\hline & VGR_al & 0.94 & 0.12 & 0.28 & 0.86 & 0.41 & 0.18 & 0.95 & -0.05 & 0.18 \\
\hline & PCD_vo & 0.97 & 0.18 & 0.07 & 0.98 & 0.00 & 0.00 & 0.97 & 0.09 & 0.16 \\
\hline & NDV1_vo & 0.94 & 0.18 & -0.04 & 0.97 & 0.13 & 0.11 & 0.94 & 0.17 & 0.17 \\
\hline & VGR_vo & 0.94 & -0.01 & 0.21 & 0.93 & 0.19 & -0.10 & 0.92 & -0.23 & 0.15 \\
\hline \multirow{5}{*}{$\mathrm{RV}$} & & $71.8 \%$ & $12.9 \%$ & $12.6 \%$ & $45.8 \%$ & $20.2 \%$ & $12.3 \%$ & $46.4 \%$ & $15.0 \%$ & $13.0 \%$ \\
\hline & Yield/m² & -0.03 & 0.97 & 0.23 & 0.02 & 0.30 & 0.95 & 0.09 & 0.97 & 0.22 \\
\hline & Berry Wt & 0.01 & 0.23 & 0.97 & 0.01 & 0.99 & 0.11 & 0.21 & 0.16 & 0.97 \\
\hline & PCD_al & 0.99 & 0.04 & 0.04 & 0.62 & 0.50 & 0.17 & 0.96 & 0.03 & 0.12 \\
\hline & NDVI_al & 0.97 & 0.06 & 0.06 & 0.08 & 0.35 & 0.17 & 0.82 & 0.15 & 0.10 \\
\hline
\end{tabular}




\begin{tabular}{llllllllll} 
VGR_al & $\mathbf{0 . 9 8}$ & 0.05 & 0.03 & $\mathbf{0 . 7 9}$ & -0.06 & -0.01 & $\mathbf{0 . 5 3}$ & -0.12 & 0.13 \\
PCD_vo & $\mathbf{0 . 9 8}$ & -0.10 & -0.03 & $\mathbf{0 . 9 2}$ & 0.31 & 0.07 & $\mathbf{0 . 9 4}$ & -0.20 & 0.08 \\
NDVI_vo & $\mathbf{0 . 9 8}$ & -0.10 & -0.04 & $\mathbf{0 . 9 3}$ & 0.23 & 0.04 & $\mathbf{0 . 9 5}$ & -0.18 & 0.11 \\
VGR_vo & $\mathbf{0 . 9 7}$ & -0.09 & -0.05 & $\mathbf{0 . 9 6}$ & -0.05 & 0.01 & 0.10 & -0.34 & 0.01 \\
\hline
\end{tabular}

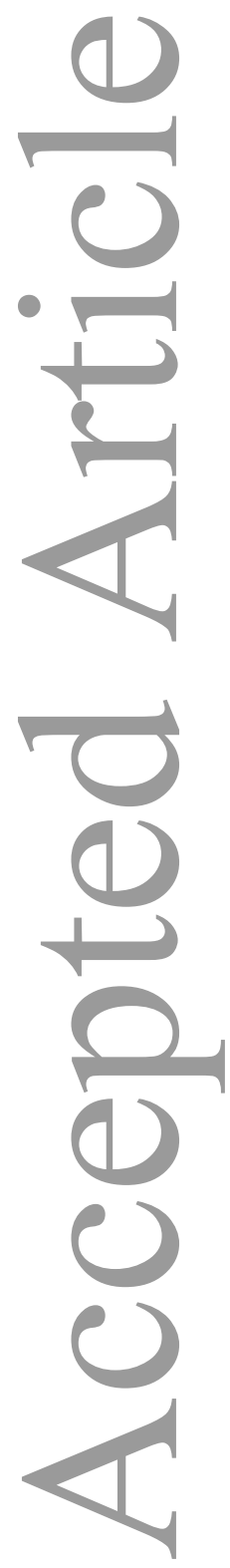

This article is protected by copyright. All rights reserved 
Table 3. Factor loadings on soil chemical and physical properties at five Shiraz vineyard sites in Southern Australia. For the GV and MD sites, two soil factors (denoted GV1, GV2 and MD1, MD2) were found to correlate with vine and berry composition variables. Cl, chloride; EC, electrical conductivity; $\mathrm{BD}$, bulk density; RAW, readily available water. The factors represent: an EC-Cl vs soil physical properties and $\mathrm{pH}$ contrast (GS), a contrast between subsoil chemistry (EC and $\mathrm{pH}$ ) and soil physical properties (GV1), surface soil compaction (GV2), subsoil salinity (LC), subsoil salinity (RV), sandy and compact subsoil (MD1 06), saline soil (MD2 07 \& 08), and subrface compaction (MD2).

\begin{tabular}{|c|c|c|c|c|c|c|c|c|}
\hline \multirow[b]{3}{*}{ Variable } & \multirow[t]{2}{*}{ GS } & \multirow{2}{*}{ GV1 } & \multirow{2}{*}{ GV2 } & \multirow{2}{*}{ LC } & \multirow[t]{2}{*}{$\mathrm{RV}$} & \multicolumn{2}{|c|}{ MD1 } & \multirow{3}{*}{$\begin{array}{r}\text { MD2 } \\
\quad 9 \% \\
\end{array}$} \\
\hline & & & & & & 06 & $07 \& 08$ & \\
\hline & $35 \%$ & $25.8 \%$ & $9.8 \%$ & $14.2 \%$ & $12.5 \%$ & $21.2 \%$ & $26.7 \%$ & \\
\hline $\mathrm{Cl} 0-10$ & -0.31 & 0.37 & 0.35 & 0.13 & -0.20 & -0.14 & 0.81 & -0.41 \\
\hline Cl 15-25 & -0.29 & 0.03 & 0.18 & 0.39 & 0.09 & -0.14 & 0.90 & -0.23 \\
\hline Cl 35-45 & -0.49 & -0.13 & 0.06 & 0.51 & 0.67 & -0.31 & 0.79 & -0.06 \\
\hline Cl 70-80 & -0.53 & -0.06 & -0.42 & 0.65 & - & -0.35 & 0.61 & 0.17 \\
\hline EC $0-10$ & -0.74 & 0.38 & 0.30 & 0.17 & 0.05 & -0.10 & 0.84 & -0.23 \\
\hline EC $15-25$ & -0.79 & -0.02 & 0.21 & 0.56 & 0.25 & -0.18 & 0.86 & -0.12 \\
\hline EC 35-45 & -0.84 & -0.35 & 0.03 & 0.52 & 0.88 & -0.34 & 0.65 & -0.11 \\
\hline EC 70-80 & -0.74 & -0.67 & -0.21 & 0.59 & - & -0.44 & 0.61 & 0.02 \\
\hline pH 0-10 & 0.46 & -0.26 & 0.26 & 0.15 & 0.05 & -0.18 & -0.09 & 0.30 \\
\hline pH 15-25 & 0.74 & -0.32 & -0.12 & 0.23 & 0.09 & -0.05 & 0.14 & 0.11 \\
\hline pH 35-45 & 0.62 & -0.79 & -0.06 & 0.60 & 0.83 & -0.05 & 0.08 & -0.19 \\
\hline pH 70-80 & 0.38 & -0.65 & 0.18 & 0.42 & - & -0.14 & 0.29 & -0.07 \\
\hline BD 0-10 & 0.59 & -0.15 & 0.69 & 0.20 & 0.15 & 0.18 & -0.28 & 0.76 \\
\hline BD 15-25 & 0.53 & 0.18 & 0.78 & 0.24 & -0.17 & 0.12 & -0.21 & 0.77 \\
\hline BD 35-45 & 0.46 & 0.68 & 0.24 & 0.51 & -0.04 & 0.72 & 0.02 & 0.31 \\
\hline BD 70-80 & 0.22 & 0.53 & 0.35 & 0.28 & - & 0.82 & -0.08 & -0.01 \\
\hline RAW 0-10 & 0.66 & 0.51 & -0.37 & -0.02 & -0.02 & - & - & - \\
\hline RAW 15-25 & 0.71 & 0.75 & -0.15 & 0.09 & 0.01 & - & - & - \\
\hline RAW 35-45 & 0.62 & 0.56 & -0.28 & 0.56 & -0.15 & - & - & - \\
\hline RAW 70-80 & 0.34 & 0.30 & -0.47 & 0.00 & - & - & - & - \\
\hline Sand $0-10$ & 0.68 & 0.85 & -0.06 & 0.19 & -0.04 & 0.76 & -0.22 & 0.20 \\
\hline Sand $15-25$ & 0.70 & 0.88 & -0.03 & 0.22 & -0.23 & 0.70 & -0.40 & 0.09 \\
\hline Sand 35-45 & 0.68 & 0.70 & -0.02 & 0.39 & -0.29 & 0.83 & -0.32 & 0.01 \\
\hline Sand 70-80 & 0.50 & 0.34 & 0.03 & 0.04 & - & 0.77 & -0.24 & 0.06 \\
\hline
\end{tabular}

This article is protected by copyright. All rights reserved 
Table 4. Relationships between factors derived from soil chemical and physical properties and berry composition after controlling for crop, berry and canopy size effects. Probabilities are shown for significant relationships otherwise a "_“ is given to denote non- significant relationships ( $p>0.05) .{ }^{1}$ Anth, anthocyanin; ${ }^{2}$ Tan, tannin; and ${ }^{3} \mathrm{TP}$, total phenolics. ${ }^{\mathrm{a}}$ Note that the loadings of the factor denoted by MD1 for 2006 season is different from 2007 and 2008 (see also Table 3 for descriptions of factor representations).

\begin{tabular}{|c|c|c|c|c|c|c|c|c|}
\hline Site & Year & Factor & TSS & $\overline{\mathrm{pH}}$ & $\mathrm{TA}$ & Anth & Tan & TP \\
\hline \multirow{3}{*}{ GS } & 6 & GS & - & - & - & - & - & - \\
\hline & 7 & GS & - & - & - & - & - & - \\
\hline & 8 & GS & - & - & - & - & - & - \\
\hline \multirow{6}{*}{ GV } & 6 & GV1 & - & - & - & - & - & - \\
\hline & & GV2 & - & - & - & - & - & - \\
\hline & 7 & GV1 & - & - & - & - & - & - \\
\hline & & GV2 & - & - & - & .029 & - & - \\
\hline & 8 & GV1 & .011 & - & - & - & - & - \\
\hline & & GV2 & - & - & - & - & - & - \\
\hline \multirow{3}{*}{ LC } & 6 & LC & - & - & - & - & - & - \\
\hline & 7 & LC & - & - & - & - & - & - \\
\hline & 8 & LC & - & - & - & - & .012 & .009 \\
\hline \multirow{6}{*}{ MD } & 6 & $\mathrm{MD1}^{\mathrm{a}}$ & - & - & - & - & - &.- \\
\hline & & MD2 & - & - & - & - & - & - \\
\hline & 7 & MD1 & - & - & - & - & - & - \\
\hline & & MD2 & - & - & .004 & - & - & - \\
\hline & 8 & MD1 & - & - & - & .- & - & - \\
\hline & & MD2 & - & - & - & - & - & - \\
\hline \multirow{3}{*}{ RV } & 6 & RV & - & - & - & - & .042 & - \\
\hline & 7 & RV & - & - & - & - & - & - \\
\hline & 8 & RV & - & - & - & - & - & - \\
\hline
\end{tabular}

This article is protected by copyright. All rights reserved 
The primary data used for the analyses presented in the manuscript are given below in the form of box plots. Sample size (each box) $=100$.

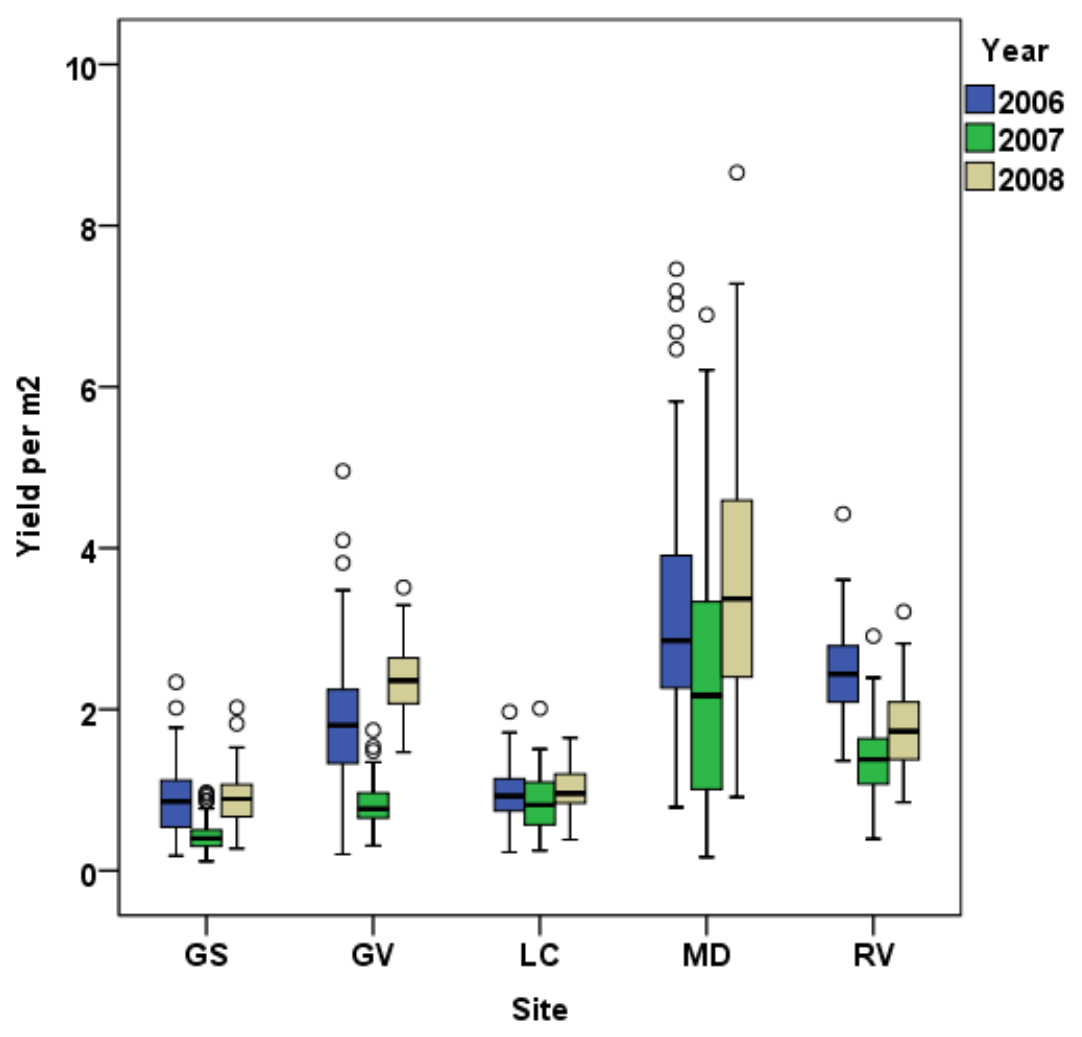

Fig. S1. Grape yield across the five sites over the three years. 


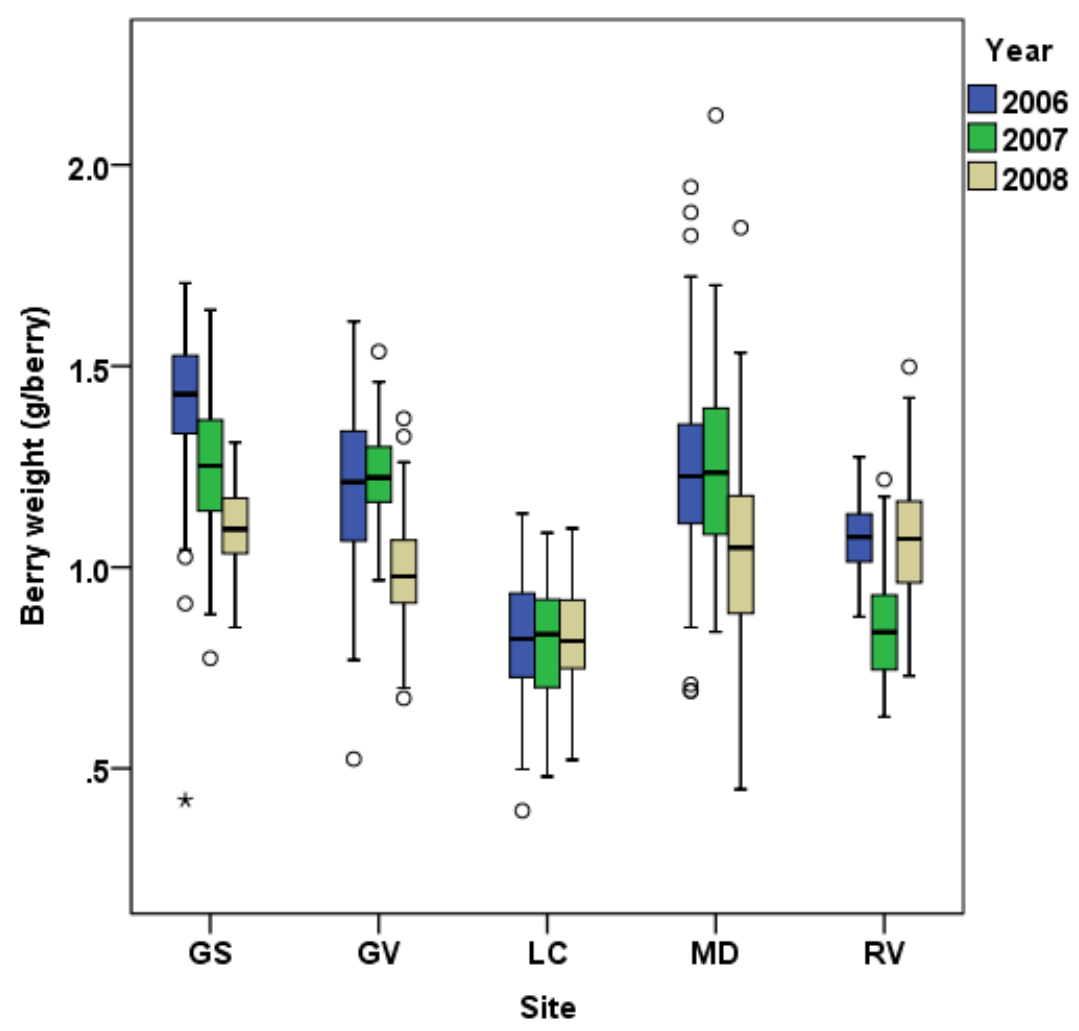

Fig S2. Variations in berry mass between regions and years. 


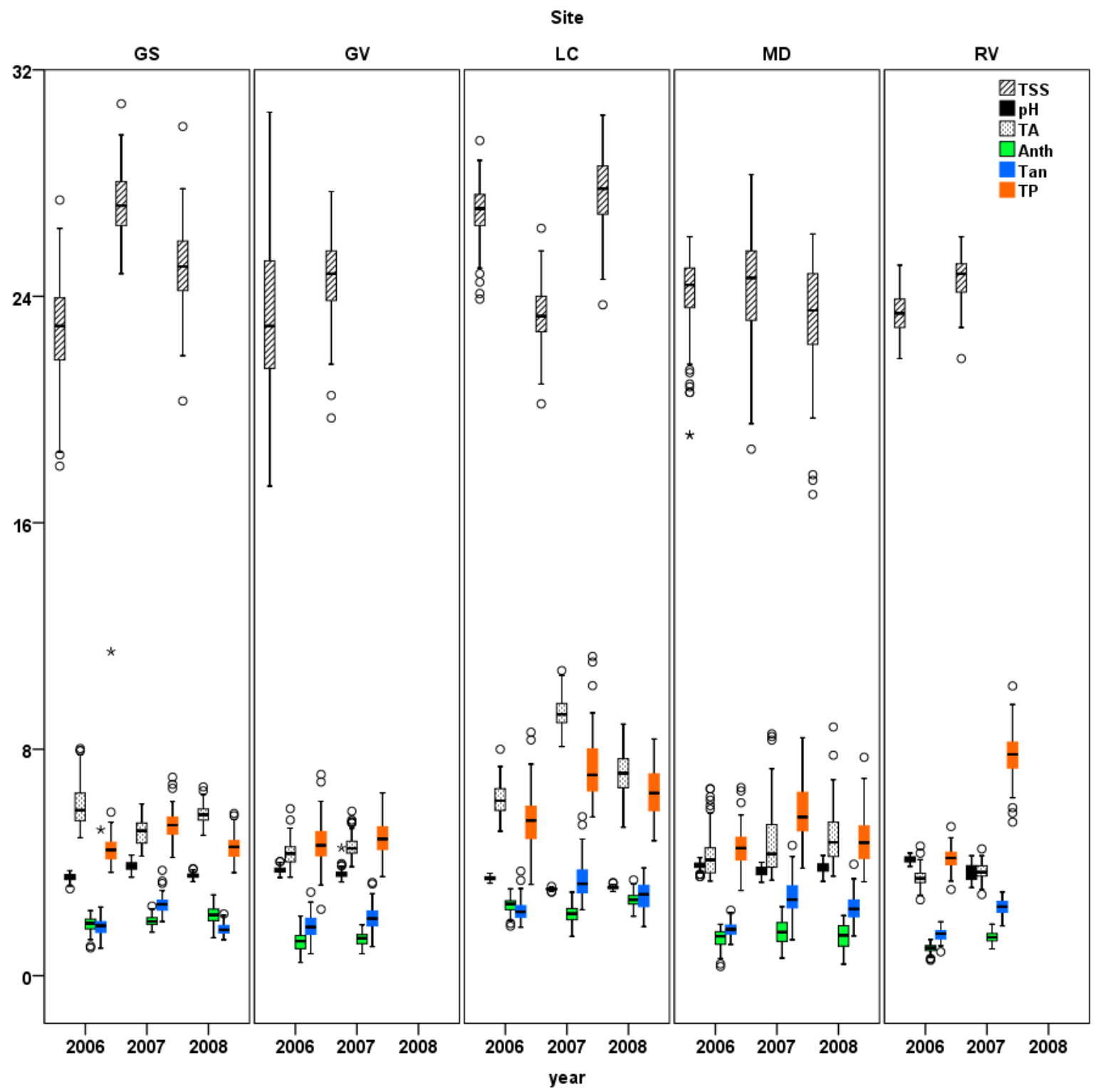

Fig. S3. Box plots showing variation in levels of berry chemistry components between regions and seasons. TSS, total soluble solids (g.kg- ${ }^{1}$ berry juice $\times 10$ ); TA, titrtable acidity (g. L $^{-1}$ as tartatic acid equivalents); Anth, anthocyanins (g. $\mathrm{kg}^{-1}$ as malvidin-3-glucodside equivalents); Tan, tannins, and TP, total phenolics, both in g. $\mathrm{kg}^{-1}$, as catechin equivalents). In all cases, $\mathrm{n}=97-100$ (for each box plot). 


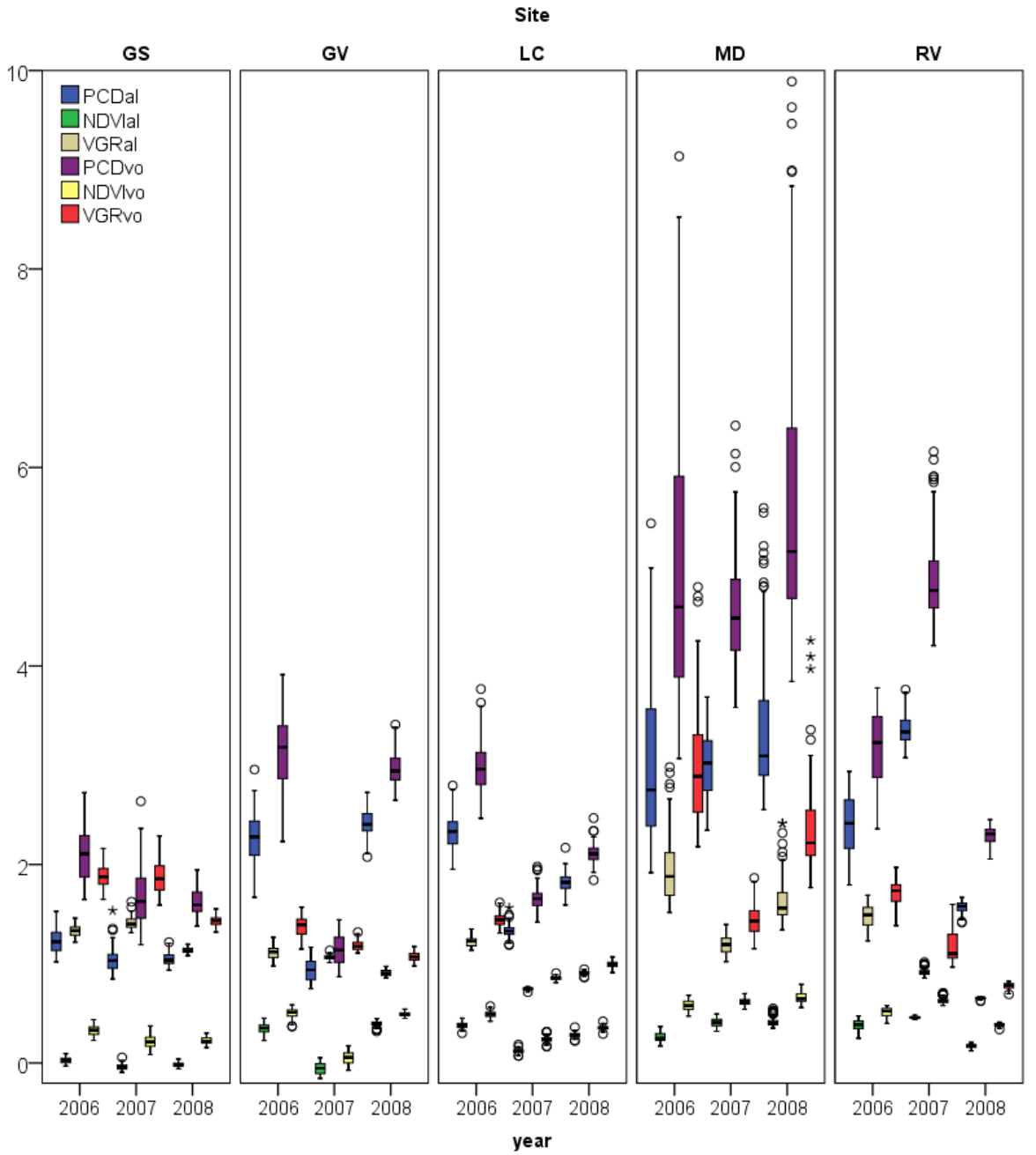

Fig. S4. Remotely sensed canopy size estimates shown by region and year. Note that comparisons are only valid within a site and within vintage. Abbreviations are detailed in the main manuscript. 


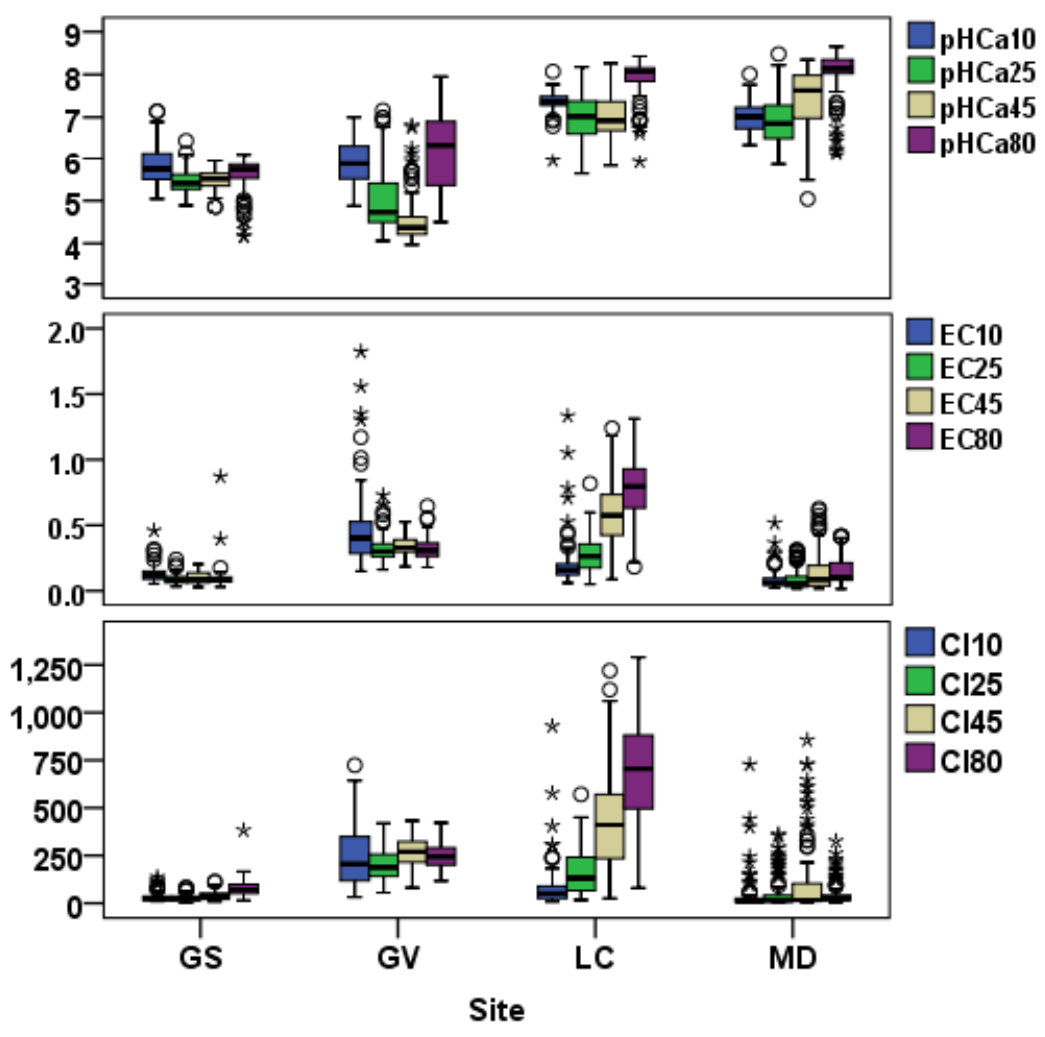

Fig. S5. Variations in soil chemical properties (pH, EC and $\mathrm{Cl})$ across and within sites. 


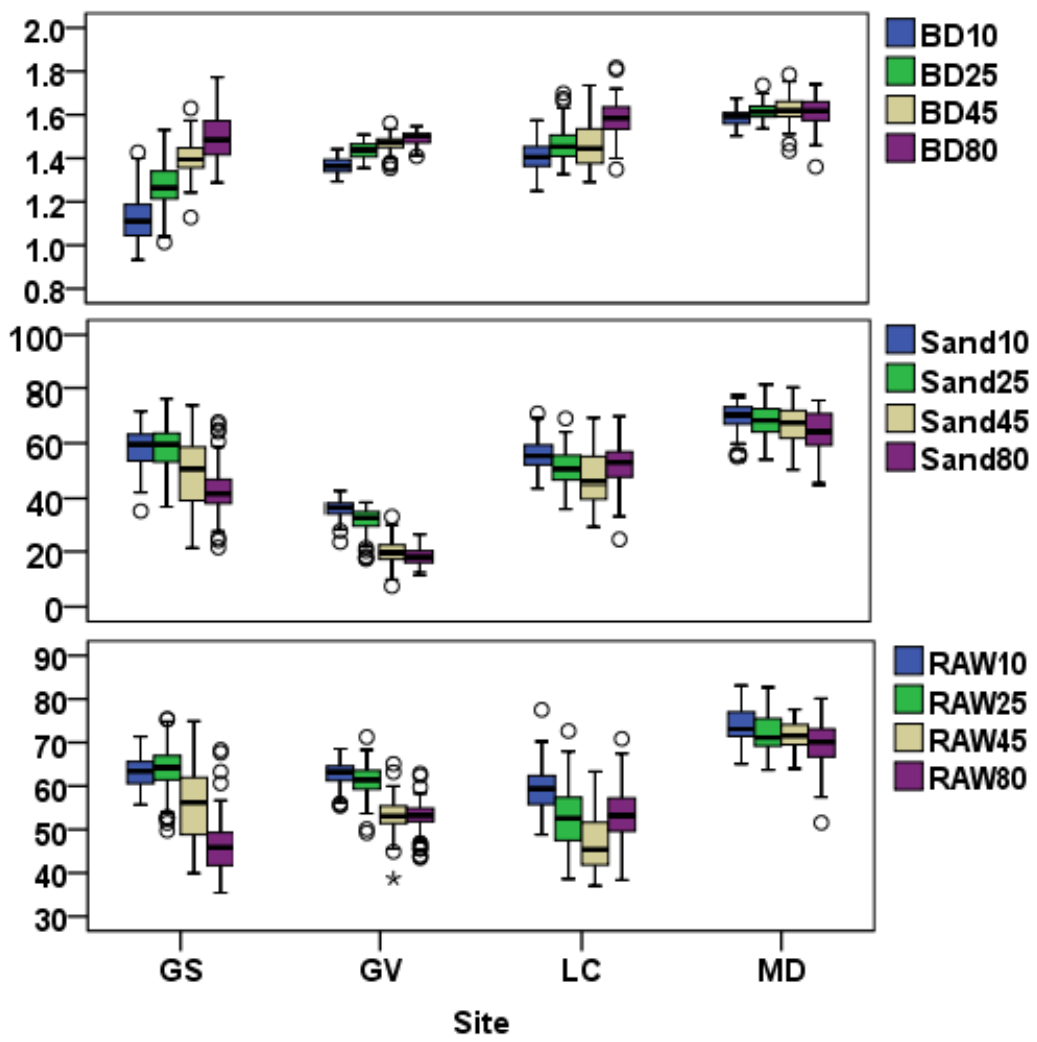

Fig. S6. Soil physical property (bulk density, sand content and readily available water) variations within and across sites. 